\title{
Transformasi Modal Sosial ke dalam Modal Ekonomi Dalam Upaya Pengentasan Kemiskinan (Studi di Pulau Lombok, NTB)
}

\author{
M. Firmansyah ${ }^{1}$, Rishan Adha ${ }^{2}$ dan Masrun ${ }^{1}$ \\ ${ }^{1}$ Fakultas Ekonomi dan Bisnis, Universitas Mataram \\ ${ }^{2}$ Universitas Muhammadiyah Mataram \\ *email korespondensi : firmansyah.feb@unram.ac.id
}

\begin{tabular}{ll}
\hline Info Artikel & ABSTRAK \\
\hline Kata Kunci: & \\
Modal sosial, & Pulau Lombok dikenal dengan sebutan Pulau Seribu \\
Kemiskinan, & Mesjid. Keberadaan banyak mesjid di Pulau Lombok \\
Aktifitas Ekonomi & merupakan gambaran modal sosial yang masih eksis. \\
& Modal sosial lain dalam masyarakat Lombok adalah \\
& perayaan maulid nabi oleh sebagian rumah tangga. Tulisan \\
& ini mencoba menawarkan gagasan modal sosial yang \\
& ditransformasikan ke dalam modal ekonomi dalam upaya \\
& pengentasan kemiskinan berbasis masyarakat. Hasil studi \\
& menunjukan: 1). Peran informal leader (tuan-tuan guru) \\
& yang mengkampanyekan ikhtiar bangun masjid dan \\
& perayaan maulid nabi bernilai sama dengan ikhtiar \\
& membantu saudara yang miskin, sehingga kedua-duanya \\
& dapat dilaksanakan. 2) perlu dilakukan revitalisasi peran \\
& masjid, di samping sebagai rumah ibadah juga sebagai \\
& pusat aktifitas muamalah (ekonomi). 3) perlunya akurasi \\
data profil masyarakat miskin di masing-masing desal \\
kelurahan sehingga penanganannya tepat sasaran dan \\
berbasis mesjid.
\end{tabular}

\section{Latar Belakang}

Modal sosial dapat ditransformasikan ke dalam modal ekonomi (Chevatonovic, et al, 2015). Hasil studi Fan (2014) di Cina menunjukan modal ekonomi, modal sosial dan modal budaya mampu menjadi pemicu ketimpangan bila tidak dikelola baik. Sehingga dapat pula dikatakan bahwa: 1) modal sosial berkualitas mampu memicu pertumbuhan modal ekonomi, 2). Modal sosial yang tidak terpelihara dapat menyebabkan keterpurukan ekonomi.

Modal sosial dalam konteks nilainilai agama menarik untuk ditelisik dalam kehidupan masyarakat Lombok (suku sasak). Atas dasar religiusitas, Lombok dijuluki masyarakat Pulau Seribu Mesjid, karena di Lombok berdiri ribuan mesjid yang tersebar di berbagai tempat. Bentuk modal sosial dalam pembangunan mesjid itu dapat diamati dalam berbagai bentuk 


\section{Elastisitas - Jurnal Ekonomi Pembangunan \\ Vol. 1 No. 1, (2019), 16 - 23}

misalnya untuk menyelesaikan pembangunan masjid dilakukan dengan gotong royong, saat ini telah terbangun lebih dari 5000 mesjid atau bila dibagi rata ada sekitar 10 mesjid di masing-masing desa. Pembangunan Islamic Center (IC) menelan anggaran puluhan miliar Rupiah yang berasal dari berbagai sumber pembiayaan.

Berdasar kualitas, masjid terbangun dengan megah dan dengan arsitektur yang tidaklah asal-asalan. Ukiran atau desain eksterior maupun interior dikerjakan secara serius dan dengan nilai seni tinggi, sehingga penyelesaian masjid kecil-pun kemungkinan menelan biaya lebih dari 3 milliar rupiah.

Dalam konteks ini, dapat dikatakan bahwa modal sosial mampu menggerakan modal ekonomi sekaligus modal fisik. Masyarakat berkontribusi secara maksimal membangun masjid, tidak saja secara finansial namun juga menyumbang tenaga, bergotong royong di hari-hari tertentu. Tenaga kerja gratisan (goton royong) ini tentu sangat membantu proses penyelesaian masjid secara cepat.

Transformasi modal sosial ke dalam modal ekonomi juga dapat ditemukan saat perayaan maulid Nabi Muhammad saw. Sebagian besar masyarakat, kaya maupun miskin merasa terdorong untuk menyelenggarakan seremonial rutin tahunan ini. Model perayaan dimaksud, yaitu rumah tangga mengundang kerabat, keluarga, kawan untuk dijamu dengan aneka makanan dan minuman. Sungguhpun seorang pembantu yang hidup paspasan namun persoalan maulid nabi tidak boleh diabaikan. Perayaan maulid nabi menjadikan harga barang relative tinggi ${ }^{1}$,

\footnotetext{
${ }^{1}$ Menurut kepala BPS Wahyudin, cuaca dan perayaan maulid nabi menjadi penyebab tingginya inflasi Kota Mataram (Lombok). Lebih jauh dapat dilihat:
}

sehingga mendorong inflasi dari sebulan sebelum hari pelaksanaan.

Di tengah kemegahan bangunan masjid dan perayaan rutin maulid nabi, masih eksis masyarakat miskin yang dengan serba terbatas memenuhu kebutuhan hidupnya. Menurut data BPS angka kemiskinan di NTB tahun 2016 tercatat 16,2 persen lebih dan masih tersentral di pulau Lombok². Data Indeks pembangunan manusia (IPM) menempatkan NTB dalam posisi yang masih rendah, artinya masih banyak masyarakat yang kekurangan ekonomi, masih rendahnya derajat kesehatan dan juga pendidikan. Pertanyaan yang kemudian muncul, pertama bila pembangunan mesjid dikontribusikan termaksud mereka yang kurang mampu secara finansial, lalu bagaimana masyarakat rela mengeluarkan uang untuk membangun masjid dengan tanpa memperhatikan kebutuhan dirinya. Kedua, bila pembangunan masjid dikontribusikan oleh sebagian masyarakat kaya, kenapa pembagunan fisik (masjid) menjadi lebih penting dari membangun masyarakat secara kolektif untuk keluar dari kemiskinan.

Atas dasar pertanyaan di atas, menjadi ruang menarik untuk ditelaah, apa instrument penting yang memungkinkan untuk mendorong transformasi modal sosial (nilai-nilai agama) itu ke dalam modal ekonomi dalam pengentasan kemiskinan. Sehingga instrument itu dapat digunakan dalam menyelesaikan masalah kemiskinan dan keterbelakangan ekonomi di Pulau Lombok.

\section{Rumusan Masalah}

http://lomboknews.com/2014/02/04/cuaca-danperayaan-maulid-penyebab-inflasi/ 2 http://elshinta.com/news/54274/2016/03/28/ting kat-kemiskinan-di-lombok-barat-masih-tinggi 


\section{Elastisitas - Jurnal Ekonomi Pembangunan \\ Vol. 1 No. 1, (2019), 16 - 23}

Studi ini memaparkan gagasan untuk mentransformasi modal sosial yang sudah tertanam dalam urusan religi (agama) ke dalam program pengentasan kemiskinan. Pertanyaan yang coba dijawab dalam penelitian ini adalah bagaimana cara memindahkan modal sosial religi ke dalam modal ekonomi dalam upaya mengentaskan kemiskinan di Pulau Lombok. Tujuan penelitian adalah untuk menemukan instrument yang tepat untuk memindahkan modal social dalam membangun masjid dan perayaan maulid nabi ke dalam program atau rancangan pembangunan ekonomi masyarakat.

\section{Litarutur Review}

\subsection{Definisi Modal Sosial}

Bila dihubungkan dengan definisi yang dipaparkan Chevatanovics et al (2015), modal sosial dalam ilmu ekonomi merupakan manfaat ekonomi yang diperoleh masyarakat dan didapat dari bantuan komununikasi, kerjasama dan kepercayaan. Masih menurut Chevatonovics et al (2015) komponen dari modal sosial adalah ikatan sosial dan jaringan yang dapat diubah menjadi modal ekonomi.

Dalam konteks keinginan masyarakat membangun masjid, dapat dianalogikan bahwa membangun rumah Allah adalah kebanggaan dan bernilai ibadah, sehingga masyarakat bekerja sama satu dengan yang lain, bahu membahu membangun masjid. Tantanganya adalah bagaimana modal sosial ini bisa diubah sebagai modal ekonomi, dalam mengentaskan kemiskinan, menciptakan lapangan kerja dan seterusnya.

\subsection{Makna Kata Modal}

Kata-kata modal (capita) dalam ekonomi adalah sesuatu yang ditanam (diinvestasikan) untuk kemudian mendapat hasil dari apa yang ditanam itu. Ada dua modal yang biasanya dikenal dan dibahas dalam ilmu ekonomi mainstream yaitu, pertama modal fisik (ekonomis) biasanya berupa uang atau alat-alat berbentuk fisik lain, kedua modal manusia yaitu menyangkut kapasitas atau kemampuan manusia dalam aktifitas ekonomi. Sehingga, baik modal fisik maupun modal manusia adalah dalam rangka meningkatkan kapasitas produksi perusahaan, saat ini banyak juga yang mengasosiasikan modal ekonomi dan manusia dengan peningkatan kapasitas pemerintahan (good government).

Modal yang sama sekali tidak diungkit dalam teori-teori ekonomi arus utama (mainstream) dan juga dalam proses pembangunan adalah modal sosial. Sungguhpun demikian, dalam perkembangannya saat ini modal sosial menjadi inti pembahasan dalam ilmu-ilmu sosial, seperti bisnis, perilaku bisnis, ilmu politik, sosiologi dan ekonomi (Bahmani, Galindo, \& Méndez, 2010). Bila modal fisik dan modal manusia cukup dikembangkan secara mandiri (parsial), modal manusia wajib membutuhkan interaksi (hubungan) sosial. Dengan kata lain interaksi sosial adalah syarat mutlak dari pengembangan modal sosial.

Modal sosial didefinisikan sebagai keuntungan dari kerjasama jaringan, yaitu, sebagai sumber daya sesuai dengan modal dan manusia (Snedsen, 2001). Definisi modal sosial yang banyak digunakan adalah yang diungkap oleh Putnam, et al (1993) yang menganggap modal sosial sebagai kepercayaan, norma dan jaringan (Bahmani et al., 2010; Forrest \& Kearns, 2001; Fragkandreas, 2012). Definisi lain modal sosial tertuang dalam pemikiran Elinor Ostrom, yang menganggap modal sosial sebagai pengetahuan, pemahaman, 


\section{Elastisitas - Jurnal Ekonomi Pembangunan \\ Vol. 1 No. 1, (2019), 16 - 23}

norma, aturan, dan harapan bersama tentang pola interaksi individu dalam kelompok menghasilkan aktivitas berulang (Fragkandreas, 2012). Namun secara garis besar modal sosial didefinisikan sebagai aset kolektif dalam bentuk norma-norma bersama, nilai-nilai, keyakinan, kepercayaan, jaringan, hubungan sosial, dan lembaga yang memfasilitasi kerjasama dan aksi kolektif yang saling menguntungkan (Bhandari dan Yasunobu, 2009).

Modal sosial dapat diukur dari tiga lingkup (Grootaert dan Bastelaer, 2002: 3; Svendsen, 2001; Bhandari dan Yasunobu, 2009) yaitu: level mikro digunakan untuk mengamati bentuk jaringan horizontal individu dan rumah tangga yang diasosiasikan dengan norma dan nilai-nilai. Level Meso adalah dalam rangka mengamati hubungan horizontal dan vertikal antar group, sedangkan makro level adalah mengamati berbagai institusi dan lingkungan ekonomi dan politik dan peraturan pemerintahan (Grootaert dan Bastelaer, 2002: 3)

\subsection{Persoalan Kemiskinan}

Mengentaskan kemiskinan selalu menjadi program prioritas yang ingin dituntaskan pemerintah. Boleh dikatakan setiap tahun anggaran penanggulan kemiskinan terus saja bertambah, namun belum secara signifikan menurunkan angka kemiskinan. Provinsi NTB misalnya, menargetkan penurunan kemiskinan 2 persen pertahun dengan anggaran yang digelontorkan lebih dari Rp. 800 miliar di tahun 2015. Faktanya hanya mampu menurunkan kemiskinan di bawah angka 1 persen. Tahun 2016 pemerintah daerah menambah anggaran penanggulangan kemiskinan menjadi lebih dari Rp. 1 triliun, harapannya angka kemiskinan mampu diturunkan 2 persen pertahun dan posisi orang miskin yang masih tercatat 16 persen dari jumlah penduduk segera ditanggulangi.

Kemiskinan adalah keadaan yang tidak diharapkan semua orang. Orang tentu berharap dapat hidup sejahtera dan berkecukupan, sehingga kebutuhan sandang, pangan dan papan serta hiburan dapat terpenuhi. Namun demikian, di mana-pun masih tetap ada yang namanya kemiskinan, baik kemiskinan itu secara asbolut maupun relatif. Dikatakan kemiskinan secara absolut di mana orang terjerembab dalam kemiskinan karena memang tidak mampu berbuat apa-apa, misalnya karena usia renta, cacat atau sama sekali tidak memiliki keahlian. Sedangkan kemiskinan relatif adalah orang relatif miskin tidak berpunya dibanding dengan keadaan orang lain.

Awalnya kemiskinan diukur hanya dari garis anggaran orang miskin (poverty line) dimana yang menjadi acuan adalah pendapatan. Namun makna kemiskinan menjadi lebih luas, yaitu terkait indikator sosial seperti kalori makanan, kondisi tempat tinggal, kematian bayi, pendidikan dan seterusnya (.

\section{Pembahasan Dan Diskusi}

Paling tidak ada dua kegiatan, tentu masih banyak kegiatan yang lain yang mengharuskan masyarakat Lombok mengeluarkan uang dalam kegiatan social kemasyarakatan, yaitu perayaan maulid nabi dan pembangunan masjid. Perayaan maulid nabi dirayakan oleh sebagian masyarakat dengan mengundang sanak kerabat untuk menghadiri jamuan makan. Bahkan sebagian masyarakat yang tergolong kurang mampu harus menabung jauh-jauh hari untuk perayaan maulid nabi. Masyarakat terdorong untuk ikut meramaikan acara rutin setiap sekali setahun ini. Dampak paling terasa dari perayaan maulid nabi adalah terjadinya 


\section{Elastisitas - Jurnal Ekonomi Pembangunan \\ Vol. 1 No. 1, (2019), 16 - 23}

inflasi di Lombok pada momen itu, hal ini menunjukan terjadinya pola peningkatan belanja masyarakat akan kebutuhan pokok.

Sumber pendanaan pembangunan masjid di Lombok umumya berasal dari swadaya masyarakat. Setiap bulan masyarakat perkeluarga menyisihkan uang, minimal Rp.50 ribu, yang merasa mampu tentu lebih besar lagi dan dilakukan secara rutin dan dijemput petugas. Salah satu contoh masjid Nurul Huda Lombok Barat yang mampu menampung 700-an jamaah. Pembangunan mesjid ini hanya mengandalkan uang swadaya masyarakat untuk merehab kubah baru se yang senilai Rp. 300 juta.

$$
\text { Menurut H.M Taufik yang }
$$
merupakan pengurus sekaligus tokoh masyarakat setempat, untuk pembangunan kubah baru dikenakan sumbangan "wajib" Rp. 100 ribu terhadap masyarakat sekitar. Di samping uang tunai masyarakat juga menyumbang bahan material. Donatur-pun terbagi ke dalam tiga tingkatan: 1) donator kelas I (orang kaya) dikenakan Rp. 2 juta, kelas II Rp. 1 juta dan masyarakat biasa ditarik Rp. 500 ribu $^{3}$. Kata kunci dari proses pembangunan mesjid ini adalah berkontribudi sesuai kemampuan. Sebagai bentuk akuntabilitas publik, pengurus masjid melaporkan jumlah pemasukan dan pengeluaran pada saat sebelum sholat Jum'at berjamaan di masjid.

Dalam menjamin pekerjaan lebih fokus, pengelola (takmir) masjid akan membentuk panitia khusus dalam menangani pembangunan masjid. Beberapa kasus, di mana bagian-bagian terkecil dari pembangunan, seperti pembangunan menara, pembangunan kubah, toilet dan lain-lain ditangani oleh panitia khusus, artinya pembangunan

\footnotetext{
${ }^{3}$ Dapat dilihat lebih jauh pada: http://sosialkeagamaan.kampungmedia.com/2015/11/23/qubah-masjid-direhabswadaya-dihimpun-sekejab-13398
}

masjid secara keseluruhan berbeda dengan panitia pembangunan bagian-bagian dari mesjid secara parsial.

Hampir seluruh masjid di Lombok sulit ditemukan masjid yang tidak lengkap (utuh), seperti hanya memiliki kubah atau menara saja, tapi kedua-duanya menjadi satu kesatuan yang harus dipenuhi. Menara tidak hanya berdiri tegak satu tapi kemungkinan terdiri dari beberapa menara, ada induk maupun menara kecil-kecil sebagai pelengkap membutuhkan dana ratusan juta rupiah. Bicara interior di dalam masjid, seperti lampu-lampu, mimbar khutbah semua terlihat mewah, bahkan untuk mimbar saja sebagian masjid langsung didatangkan dari pengerajin Jepara.

Semangat yang ditunjukan masyarakat sebagai akibat masih kuatnya modal sosial, yaitu nilai-nilai, cara pandang bahwa menyelenggarakan maulid dan membangun rumah ibadah adalah kebanggaan dan juga kewajiban bagi sebagai umat islam di Lombok. Masyarakat tidak saja harus mengeluarkan uang untuk pembangunan masjid, namun seringkali berduyun-duyun datang ke masjid bila dipanggil untuk kerja bakti (lihat misalnya: Faoziah, 2016) ${ }^{4}$.

Secara konseptual motif orang mengeluarkan uang dalam membangun masjid tentu beragam, dianataranya: 1). Ada yang benar-benar iklas bahwa bangun masjid adalah ibadah, 2). Ada-pula sekedar malu bila tidak berkontribusi, 3). Menunjukan eksistensi dan kekayaan, dan 4) lain-lain. Apapun motifnya, masjid selesai dibangun dan dalam waktu yang relative singkat. Dari dua contoh modal social di atas, memberi jalan pemikiran untuk mencoba melakukan transformasi untuk juga di arahkan pada program

4

http://www.kompasiana.com/ozi/menumbuhkanbudaya-gotong-royong-sukusasak_5703237823b0bd76048b456d 


\section{Elastisitas - Jurnal Ekonomi Pembangunan \\ Vol. 1 No. 1, (2019), 16 - 23}

pengentasan kemiskinan berbasis masyarakat. Dasar pemikirannya, ketika masyarakat mampu secara suka rela mengeluarkan uang untuk perayaan maulid nabi dan pembangunan masjid, tidakkah memungkinkan juga bisa dilakukan hal yang sama untuk pengembangan usaha umat dalam rangka pengentasan kemiskinan.

\subsection{Model Transfer Modal Sosial: Sebuah Penawaran}

Kemiskinan secara garis besar dapat terjadi secara struktural yaitu akibat kesalahan (mal) kebijakan dan juga secara kultural yaitu pola perilaku, budaya atau kebiasaan masyarakat. Salah satu unsur kemiskinan kultural itu misalnya merasa miskin sebagai hal biasa sehingga tidak perlu upaya serius untuk keluar dari lingkaran kemiskinan tersebut, bahkan sebagian ada yang merasa nyaman dengan kondisi yang ada. Dengan potensi ekonomi yang masih terbuka lebar saat ini, sebenarnya masih terbuka luas ruangruang untuk masyarakat bekerja atau mencari nafkah sehingga keluar dari lingkaran kemiskinan. Namun keterbatasan pengetahuan, keterbatasan akses bahkan kebiasaan, kepercayaan yang menyebabkan ruang-ruang pekerjaan tidak sepenuhnya terisi. Sehingga, umumnya masyarakat daerah lain (pendatang) yang mengisi ruang-ruang tersebut, hal ini ditunjukan banyak penjual makanan di jalan-jalan raya di malam hari yang berasal dari luar Lombok.

Provinsi NTB adalah daerah yang tercatat masih relative tinggi angka penduduk miskin, yaitu lebih dari 17 persen dari total penduduk. Kemiskinan seperti yang diketahui membawa serta rendahnya kualitas sumber daya manusia atau sebaliknya rendahnya kualitas sumber daya manusia berimplikasi pada kemiskinan. Hal ini dapat terlihat dari rendahnya IPM NTB yang urutan 30 dari 33 provinsi. Kondisi buruknya sumber daya manusia berdampak rendahnya persepsi kenyamanan berinvestasi di daerah. Hal ini terkait lokasi berinvestasi, di mana investor dalam memutuskan menanam modal biasanya di daerah yang kualitas tenaga kerjannya terjamin. Di samping itu, rendahnya kualitas manusia (secara keilmuan dan relegi) secara teori melahirkan kriminalitas, sehingga lingkaran setan kemiskinan menjadi sulit diputus.

$$
\text { Upaya-upaya pengentasan }
$$

kemiskinan yang selama ini dilakukan masih parsial berasal dari kontribusi pemerintah daerah, melalui program pengentasan kemiskinan. Ada beberapa kegiatan yang dilakukan dalam mengentaskan kemiskinan, antara lain: program bedah rumah orang miskin, bantuan sosial, raskin (beras miskin), pelatihan wirausaha terhadap KUBE (Kelompok Usaha Bersama) dan seterusnya. Namun demikian, program yang dijalankan pemerintah tidak cukup efektif dalam pengentasan kemiskinan. Alasannya, pertama, kemiskinan selalu berkaitan dengan garis kemiskinan (poverty line) yang ditentukan oleh kenaikanan harga (inflasi), sementara inflasi tidak saja bersumber dari dalam daerah namun juga dari luar (eksternal) kendali pemerintah daerah seperti kenaikan harga BBM, elpiji, listrik dan seterusnya. Kedua, kemiskinan yang paling sulit dientaskan adalah kemiskinan kultural (perilaku), sebagian masyarakat miskin tidak merasa terganggu dengan kehidupan yang serba terbatas, Ketiga, program-program pemerintah lebih kepada program fisik dan yang terukur, sementara mind set, modal sosial belum tersentuh secara maksimal dalam penanggulan kemiskinan.

Mengingat berbagai keterbatasan keuangan pemerintah daerah maka salah satu jalan yang belum sepenuhnya ditawarkan adalah mengoptimalkan peran serta masyarakat secara koletif. Artinya 


\section{Elastisitas - Jurnal Ekonomi Pembangunan \\ Vol. 1 No. 1, (2019), 16 - 23}

perlu ada jalur lain selain program resmi pemerintah, yaitu jalur kelembagaan yang terdiri dari tata nilai dan norma-norma. Semangat modal sosial berupa nilai-nilai yang cukup kuat dalam perayaan maulid nabi dan membangun masjid, karena berurusan dengan kebanggaan dan peribadatan, dan juga melaksanakan peringatan maulid nabi dengan menyediakan berbagai makanan dan minuman (kaya maupun miskin) setiap tahun menunjukan bahwa kekuatan masyarakat sebenarnya dapat diandalkan dalam mengentaskan kemiskinan. Maka modal sosial yang telah eksis dapat direkayasa (didesain) untuk digunakan dalam upaya pengentasan kemiskinan.

Ada beberapa instrumen yang perlu dipersiapkan dalam melakukan transformasi modal sosial ini: Pertama, perlu dibangun pemahaman (mind set) secara kolektif atau semacam gerakan besar yang terus dikampanyekan bahwa mengentaskan kemiskinan juga bagian dari hukum (syariat agama) bukan hanya membangun rumah ibadah. Secara syariat orang dituntut untuk kaya, sehingga dapat membantu orang lain dan berlipat ganda pahala dan secara syariat manusia berkewajiban menolong manusia yang lainnya. Bahkan mungkin derajat membantu orang lain bahkan lebih tinggi dari berkontribusi dalam membangun masjid.

Kedua, Masyarakat Lombok adalah masyarakat yang cukup patuh terhadap perkataan tuan-tuan guru sebagai informal leader, dengan demikian peran tuan guru yang terus mengkampanyakan gerakan pengentasan kemiskinan akan relative efektif merubah perilaku dan mind set masyarakat untuk sama-sama melawan dan keluar dari lingkaran kemiskinan. Masing-masing desa perlu ada informal leader di samping formal leader (kepala desa). Informal leader ini harus diberi pengetahuan serta pemahaman oleh pemangku kepentingan dalam mengeksplorasi kekuatan-kekuatan sosial dalam masyarakat sebagai senjata pengentasan kemiskinan.

Ketiga, melakukan revitalisasi peran masjid. Pengetasan kemiskinan tidaklah identik dengan bantuan uang kepada fakir miskin, namun dapat dibuatkan lembaga keuangan khusus miskin yang tidak terlepas dari kepengurusan masjid. Mesjid di samping sebagai rumah ibadah juga dapat menjadi pusat kelembagaan muamalah yang mengatur banyak hal, seperti pendidikan agama, pengelolaan keuangan semisal koperasi islam, pusat pelatihan entrepreneur islami dan seterusnya. Perlu diintegrasikan pusat kebanggaan masyarakat (berupa masjid) ini ke dalam program-program lainnya.

Keempat. Pengentasan kemiskinan adalah pekerjaan luas yang terintegrasi, termasuk persoalan akurasi data kemiskinan sehingga perlu dilakukan pendataan masyarakat miskin secara riil berbasis desa atau RW sampai dengan rencana aksi pengentasan kemiskinan berbasis masyarakat. Pengurus masjid atau lembaga di bawahnya harus didorong untuk mengelola secara professional termasuk penguatan data masyarakat miskin di unit-unit terkecil masyarakat sehingga menjadi acuan bagi masjid untuk langsung membantu orang miskin by name by adress.

\section{Penutup}

Sebagian kalangan yang peneliti ajak diskusi berkaitan dengan gagasan ini merasa pesimis dapat merubah kebiasaan atau memindahkan modal sosial masyarakat sasak ke dalam modal-modal ekonomi seperti penjelasan dalam artikel ini. Hasil studi ini menunjukan terdapat ruang untuk memindahkan modal sosial itu dalam upaya pengentasan kemiskinan. 


\section{Elastisitas - Jurnal Ekonomi Pembangunan \\ Vol. 1 No. 1, (2019), 16 - 23}

Instrumen yang ditawarkan dalam penelitian ini merupakan bentuk rekayasa kelembagaan masyarakat (tata nilai, kebiasaan dan norma). Kelembagan itu sendiri tidak bersifat statis, kelembagaan berjalan tergantung bagaimana kelembagaan itu terus dikampanyekan, dijadikan gerakan sehingga menjadi kebiasaan baru. Walaupun butuh waktu dan proses yang lama dan panjang, bukan berarti pemangku kepentingan abai untuk dicoba dan dikembangkan.

\section{Daftar Pustaka}

Polishehuk, L dan Meniashev, R. (2011) Economics significance of social capital. International Bibliography of Social Sciences (IBBSS) Vol. 12. Pages: 46-65

Lopez, A dan Kulkarni, K, G. (2006). Role of the social capital in economic development: a case of (the East European) Georgia. Indian journal of economics, 07/2006, No.07. Vol. IXXXVII, Issue 344

Bahmani, S., Galindo, M.-Á dan Méndez, M. T. (2010). Non-profit organizations, entrepreneurship, social capital and economic growth. Small Business Economics, 38(3), 271-281

Forrest, R., \& Kearns, A. (2001). Social Cohesion, Social Capital and the Neighbourhood. Social COHESION, SOCIAL CAPITAL AND THE NEIGHBOURHOOD, 38(12), 21252143

Fragkandreas, T. (2012). International Review of Sociology: Revue Internationale de Sociologie Reflections on social capital and economic performance. International Review of Sociology-Revue Internationale de Sociologie, 22(2), 529-271.

Bhandari, H dan Yasunobu, K. (2009). What is social capital? A comprehensive review of the concept. Asian journal of social science. No.1 Vol. 37, Issue 3

Svendsen, Gunnar Lind Haase, 2001. What Is Social Capital? Dansk Sociologi. No.4, Volume 12, Issue 1

Christiaan Grootaert dan Theirry Van Bastelaer. 2002. Understanding and Measuring Social Capital a multicipline Tools for Practicioners. World Bank: Washintong 


\section{Elastisitas - Jurnal Ekonomi Pembangunan}

Vol. 1 No. 1, (2019), 16 - 23

LAMPIRAN.

Lampiran 1.

Gotong Royong Pembangunan Mesjid Mujahidin Perumnas Ampenan Mataram, gambar bagian atas (lantai. 2) masjid.

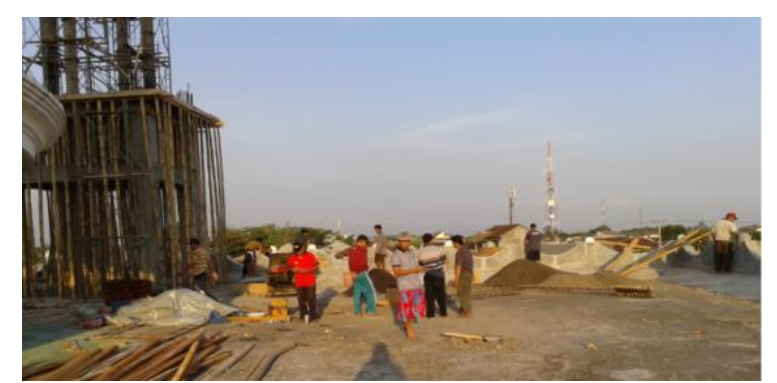

Sumber: Dokumen Pribadi

Lampiran 2. Bagian Dasar Mesjid Mujahidin Ampenan Mataram

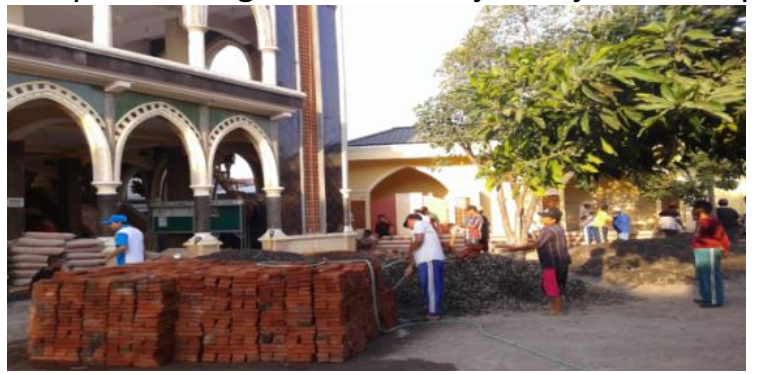

Sumber: Dokumen Pribadi

Lampiran. 3. Masyarakat melakukan estafet menaikan material ke lantai 2

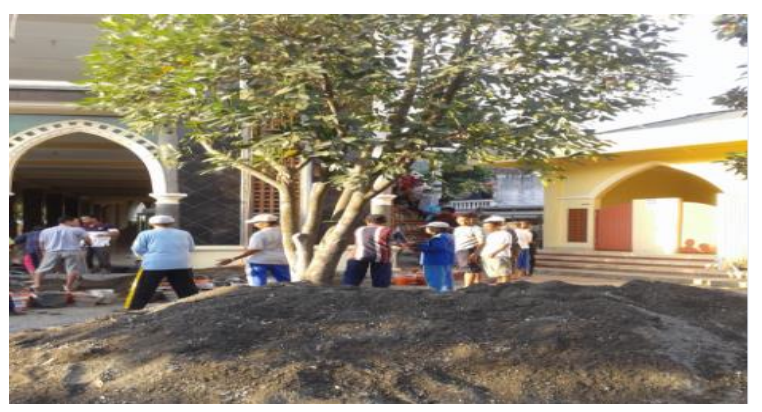

Sumber: Dokumen Pribadi 